\title{
The Added Value of the Plural Form: Evidence from Dutch Pharmacy Chains
}

\author{
Rosalie Andewereld-Duijvis ${ }^{1}$, Ed Peelen ${ }^{2},{\text { Kees van } \text { Montfort }^{3} \& \text { Harry Commandeur }}^{3}$ \\ ${ }^{1}$ Nyenrode Business Universiteit, Breukelen, Netherlands \\ ${ }^{2}$ ICSB, Rotterdam, Netherlands \\ ${ }^{3}$ Erasmus Universiteit Rotterdam, Rotterdam, Netherlands \\ Correspondence: Ed Peelen, ICSB, Rotterdam, Netherlands. Tel: 31-10-452-8602. E-mail: ed.peelen@icsb.nl
}

\author{
Received: March 8, 2013 Accepted: June 27, $2013 \quad$ Online Published: November 7, 2013 \\ doi:10.5539/ijms.v5n6p15 URL: http://dx.doi.org/10.5539/ijms.v5n6p15
}

\begin{abstract}
Most empirical work on governance decisions focuses on explaining a firms' choice among governance structures. Nevertheless, in practice very different governance structures often exist side by side. The simultaneous use of different governance structures for the same function is referred to as the "plural form". The synergistic benefits of the plural form have been highlighted by only a number of research works. We will add to the body of knowledge by studying the plural dynamics in the pharmaceutical industry. We will show the chain operator's contribution to the performance in pure and plural forms, for both company owned and franchised outlets. Further, we will open the black box and show how horizontally and vertically the interactions between franchisees, company outlets and the chain operator support the realization of potentially conflicting strategic objectives of local responsiveness and standardization. We will take the perspective of the chain operator, being responsible for the development of the plural dynamics within the organization.
\end{abstract}

Keywords: plural form, pharmacy, governance

\section{Introduction}

Most empirical work on governance decisions focuses on explaining a firms' choice among governance structures. These works consider this choice as a function of circumstances. Under certain circumstances, one governance structure does better than another. Nevertheless, in practice very different governance structures often exist side by side. Many retail chain organizations, for example, use both franchise and company-owned outlets (i.e. outlets that are owned by the chain operator). Also in other marketing settings, firms use different governance structures simultaneously. For example, firms often make and buy parts (Heide, 2003); alternatively, they sometimes use a direct sales force and third party distributors (Anderson \& Buvik, 2001). In the literature the simultaneous use of different governance structures for the same function is referred to as the "plural form" (Bradach \& Eccles, 1989; Bradach, 1997).

The first explanations concerning the use of the plural form have been limited to specific conditions. For instance, according to Brickley, Dark \& Weisbach (1991), the combination of franchise and company-owned outlets within a system is based on monitoring costs. As company-owned outlets incur higher monitoring costs, they are located near company headquarters, while as franchise outlets incur lower monitoring costs, franchising occurs in more distant locations. Some researchers have started to shed the assumption that one particular governance structure is obviously superior under certain conditions. Rather than (just) the product of micro level conditions, they argue that the plural form is the product of the synergistic potential of different governance structures.

The synergistic benefits of the plural form have been highlighted by a number of research works (e.g. Bradach \& Eccles, 1989; Dant et al., 2003; Lafontaine \& Kaufmann, 1994) and then have been further developed and empirically validated by Bradach $(1992,1997)$. In his exploratory research, Bradach studied how restaurant chains use a plural form to better meet their key strategic objectives (e.g. uniformity and local responsiveness). He explained that differences in the organization and management of franchise and company-owned restaurants can cause certain processes, which he calls "plural dynamics", across these restaurants. For instance, due to their stronger incentives, franchisees are motivated to search for revenue enhancing ideas, which can be used later in 
company-owned restaurants. According to Bradach, these plural dynamics enable operators of plural restaurant chains to better meet their strategic objectives. Hence, he predicts that plural chains outperform pure chains (i.e. chains that consist only of franchise outlets or company-owned outlets).

After Bradach, a number of scholars have conducted empirical research on the synergistic benefits of the plural form on the firm level. For instance, Botti, Briec \& Cliquet (2009) studied the advantages of having both franchise and company-owned outlets for hotel chains, and Lewin (1997) examined as the first the implications of a mixture of franchise and company-owned outlets for innovation within restaurant chains. Ehrmann \& Spranger (2004) conducted a survey among 240 franchise systems and found that less opportunistic behavior in plural forms. A cross cultural comparison has been made by Dant et al (2008). Some other scholars have studied the benefits of the plural form outside the context of franchising systems. For example, in the context of industrial purchasing, Heide (2003) investigated whether firms can better manage information asymmetry problems by augmenting market relationships with internal organization.

One of the omissions in these studies is that a comparison between pure and plural forms on an outlet level and firm level is missing. Also the how question is only addressed partly. Bradach focuses on the structural characteristics of organizations that influence the plural dynamics mechanism. But an in-depth look into how positive interactions between franchisees, company outlets and the chain operator take place, result in synergies and in a superior realization of conflicting strategic objectives (efficiency, growth, standardization and local responsiveness), misses (O'Reilly \& Tushman, 2007). This is in itself an interesting topic, particularly since the plural form will result in an increased complexity in the organization. Horizontally and vertically coordinating these interactions within different governance models is not easy (Nunn, 2007).

This article deals with the investigation of the benefits of the plural form for Dutch pharmacy chains. In the Netherlands the pharmacy sector has been characterized by considerable consolidation in the past years. Approximately $59 \%$ of the Dutch community pharmacies are currently part of a chain organization. The reasons for this chain development are diverse. For example, the last decade, it has become considerably easier for non-pharmacists to exploit pharmacies in the Netherlands. In reaction to this measure, various parties, particularly pharmaceutical wholesalers, have started to acquire pharmacies. The measures imposed by the Dutch government to control the expenditure on pharmaceutical aid have also played an important role in the development of pharmacy chains. These measures have caused the margins of pharmacies to be under increasing pressure. In combination with uncertainty about future measures, this has made many pharmacies to opt for the security of a chain organization. Dutch pharmacies chains are organized in different ways. Two chains use a mix of franchise and company-owned pharmacies. Other pharmacy chains consist either of franchise pharmacies or of company-owned pharmacies. Operators of these chains often consider extending their chains with company-owned pharmacies respectively franchise pharmacies.

We base our work on Bradach's qualitative research $(1992,1997)$. We examine to what extent his findings with respect to the benefits of the plural form can be applied to the Dutch pharmacy sector. In addition, we investigate to what extent the chain operator is capable of contributing to the plural dynamics within the entire organization, and to the extent this will result in a superior performance, i.e. the realization of strategic objectives. Finally, broadening Bradach's work to other retail sectors will create a more complete understanding of the possible added value of the plural form.

Similar to Sorenson \& Sorenson (2001) and Srinivasan (2006), we also study the performance implications of the plural form. A distinction is made between two types of performance: the performance of chain operators (i.e. the effectiveness of chain operators in achieving their strategic objectives and their contribution to the performance of pharmacies) and the performance of pharmacies. By investigating pharmacy performance, we can determine whether pharmacies benefit from being part of a plural chain. Thus whether plural dynamics lead to enhanced pharmacy performance.

\section{Theoretical Framework}

In an influential article, Bradach \& Eccles (1989) criticized the traditional "make-or-buy" principle. They invoke the concept of tapered integration (Harrigan, 1984) to argue that firms often purposely combine distinct governance structures for the same function. In their view this combination of governance structures (what they refer to as the "plural form") enables firms to reap certain synergistic benefits that are unavailable if only one ideal governance structure is used. That is, the existence of one governance structure complements and benefits the management of the other structure and vice versa. The benefits of a combination of governance structures have been highlighted by several research works. For example, Harrigan (1984) described that firms that are backward or forward integrated and that rely on outsiders for a portion of their supplies or distribution, can 
monitor the R\&D developments of the outsiders, reduce vulnerability to strikes and shortages within their systems, and examine the products of competitors, while enjoying the lower costs and greater advantages (and profit margins) of vertical integration. In the context of franchising systems, Bradach \& Eccles (1989) explained that franchisees may spot new ways of enhancing efficiency which then can be employed in company-owned outlets. In the same way, company-owned outlets may provide more information that enables firms to negotiate with and control franchise outlets effectively. Dant et al. (1992, 2003) further also identified some of the synergistic benefits specific to franchising systems. For instance, franchisees can be a source of innovative products and business ideas for future growth, while company-owned outlets may serve as efficient laboratories for market testing of new ideas before these ideas are promoted to franchisees.

Bradach $(1992,1997)$ has probably contributed the most to the existing knowledge of the benefits of the plural form. He studied how restaurant chains use franchise and company-owned outlets to better meet their strategic objectives. Bradach identified four different strategic objectives of restaurant chains: unit growth (i.e. growth in the number of outlets), local responsiveness and standardization (system wide adaptation and maintaining the standards). He explained that franchise and company-owned outlets differ considerably from each other with respect to the way in which their relationship with the chain operator is structured. According to Bradach, these differences give rise to certain plural dynamics between the chain operator and franchise and company-owned restaurants. For example, by implementing new standards in company-owned restaurants, a chain operator shows its commitment to these standards, which makes it easier to persuade franchisees to implement them as well. Or, for example, following Dant et al. (1992), Bradach considers franchisees to be an important source of innovative product and business ideas in contrast to company managers. According to Bradach, such plural dynamics enable restaurant chains that have adopted the plural form to better meet their strategic objectives. Hence, his central claim is that plural chains outperform pure chains.

To study the plural dynamics within the pharmaceutical market we follow upon Bradachs work. We include three of the four strategic objectives he distinguished, excluding unit growth. The majority of pharmacists have sold their practice or joined a franchise organization and as such this dimension is less relevant in the current market circumstances. Based upon his model and in-depth interviews (Andewereld-Duijvis, 2008) with pharmacists and pharmaceutical chain organizations we designed a model for the dynamics within the organization between chain operators, franchisees and chain outlets within pure and plural forms. It shows how each provides input, participates in decision making, follows up instructions to build an organization that meets the strategic objectives.

\section{Local responsiveness}

Local responsiveness is the extent to which firms anticipate and react to conditions in their local environment. The responsiveness of the entire organization will be taken to a higher level if there are positive interactions between the franchisees, headquarters and the company owned outlets. Therefore we focus on the following activities:

1) generating marketing intelligence through monitoring in consumers' needs and preferences, environmental scanning of competitors, technology and government regulations (Kohli \& Jaworski, 1990, 1996). Marketing intelligence is an antecedent of a firm's responsiveness.

2) participating in the chain operators' decision making process and as such contributing to the idea generating process.

3) copying other pharmacies local responses. We expect this behavior more with chain operators than with franchisees.

Compared with Bradach, we approach this aspect in more detail and with more structure.

\section{Uniform standards}

Plural dynamics also originate from pharmacies pushing chain operators to come up with ideas for innovations, forming elements of the upcoming new uniform standards. As such pharmacies positively influence the proficiency of the chain operator to generate ideas.

New ideas result in innovations, which usually are tested in the field. We assume there is a relationship between pharmacies' participation in field testing and the chain operator's contribution to general performance. When innovations are tested in a number of pharmacies, possible flaws can be removed before they are implemented in other pharmacies.

The quality of chain operator's ideas and decisions will be further improved if pharmacies give regular feedback. 
They challenge the chain operator and ask him to explain the rationale behind the decisions. Pharmacists are more likely to comment on the chain operator if they are listened to and if their comments are taken seriously.

Once the chain operator has decided to implement a uniform standard, the next step is to actually implement it. As the number of pharmacies implementing the standard increases, so to increases the uniformity that exists within the chain.

\section{Performance (realizing the strategic objectives)}

Plural dynamics will influence the performance of the entire organization. If the described positive feedback mechanisms are in place and function, we expect plural pharmacy chains to show greater effectiveness in meeting their strategic objectives than pure pharmacy chains. We expect them to contribute more to the pharmacy performance. This is however only the case if franchisees contribute to the idea generation process through their local responsiveness, if the resulting new products and services are field tested, if there is a challenging dialogue between the local pharmacists and the chain operator resulting in better new standardized products and services, and if these are actually implemented. In case this positive feedback system is not in place (yet), we might expect it to add costs, reduce efficiency, to slow down processes due to intensive communication, and to reduced focus. Since the pure and plural chains in the pharmaceutical market are of recent date, the mechanism is being developed. Local pharmacists have a background as medical professionals, and not yet as entrepreneurs being sensitive to the local environment. The origin of the chain operators lies in wholesaling, not yet in retailing. Formulas for retail pharmacies are under construction. Major programs focus on total quality management and the improvement of the quality of back office processes.

On an outlet level plural dynamics also influence performance. The interactions between franchisees and the chain operator will ask for resources, but also have the potential of bringing benefits. In plural forms when the feedback mechanisms functions properly franchisees can achieve better efficiency, professionalism and maintain a good level of local responsiveness. In pure forms the franchisees will show more local responsiveness, but score less on the standardization. And company owned pharmacies will show lower scores on local responsiveness, but higher scores on standardization. This will be the case in both the pure and plural forms, the latter however being even more standardized and less responsive.

However, if the interactions between outlets and the chain operator lack, or are not effective (yet), performance outcomes will differ. If for example franchisees in a plural form are not able to contribute to and to benefit from the chain operator during the stages of the innovation process there performance will be worse than their colleagues in pure franchising organizations. The same holds for the chain owned pharmacies in plural chains.

\section{Hypotheses}

The impact of the plural governance mechanism depends strongly on management at chain operator's headquarters on the extent to which they can develop a positive feedback system. It is their responsibility to grow the synergies. They will have to learn to tap into the local market intelligence of local franchisees (if it is there), form ideas, translate them into professional innovations that both franchisees and company owned outlets can profit from and can help them reach their strategic objectives. And: they have to learn to improve the efficiency of the organization through the introduction of standards. Initial progress will be realized easier with company owned pharmacies, who are under direct control of the chain operator (Couglan, Anderson, Stern \& El Ansary, 2006).

We expect chain operator's contribution to franchisees will initially be by enhancing their local responsiveness by contributing to the innovation process. In essence this will be the easiest in the pure form. Since chain operators can direct and control their own pharmacies better than franchisees, they will experience a higher contribution than other pharmacies from headquarter in the field of efficiency and standardization. It will be highest in the pure form, where there are strict lines and minimum dialogue.

\section{Hypothesis 1}

Chain operators' contribution to local responsiveness, idea generating proficiency and effectiveness is highest for franchisees in pure forms.

\section{Hypothesis 2}

Chain operators' contribution to efficiency, the adherence of front office and back office standards will be highest for company owned pharmacies in pure forms.

The potential value of the plural form will come out if local responsiveness and standardization are blended, merged. Both on a company and on an outlet level. The plural mechanisms in the pharmaceutical organizations 
are however of recent dates. In depth interviews we discovered the franchise formulas are not finalized yet. They are in their early development stage and need further completion and professionalization. Contracts with participants are still rather incomplete. Management towards company outlets is not fully finalized. Directions are not clear or incomplete. Research done by Nunn (2007) shows that in these circumstances both the vertical integrated (company owned pure form) and the pure franchising form are non optimal; the plural governance mechanism does not pay of yet. Since coordination mechanisms are not fully developed yet, also in plural forms the potential of the combination of the two forms is not fully exploited. Since complexity increased in plural forms, the expectation is that the performance in plural forms is even lower than in the pure forms.

\section{Hypothesis 3}

Outlets in pure forms will outperform the performance of outlets in the plural forms.

\section{Research Methodology}

Our sampling frame consisted of pharmacies of plural chains and pharmacies of pure chains. We also included pharmacies of pure chains because this allowed us to determine whether significant differences indeed exist between these two types of pharmacies. As far as the pure chains were concerned, we selected the three largest ones in the Netherlands: Mediveen, Lloyds (both only company-owned pharmacies), and Service Apotheek (only franchise pharmacies). All three pharmacy chains have more than 50 outlets. The two plural chains that were the object of the case study, Kring-apotheek/Alliance Apotheek and Escura Apotheek, were also selected for the survey. Both pharmacy chains have more than 75 outlets. Escura Apotheek holds majority shares $(100 \%)$ and minority shares in its pharmacies. We only sent the survey to those pharmacies that are fully owned by Escura Apotheek. This is due to the fact that pharmacies in which Escura Apotheek has a minority share are not obliged to join the Escura Apotheek formula, and therefore are not always members of this formula. We chose to send the survey to managing pharmacists. A managing pharmacist is the one who is daily in charge of the pharmacy. We expected these pharmacists to be best able to answer our questions.

The survey was sent to 794 pharmacies by mail. Pharmacists needed approximately 30 minutes to complete the survey. In total 159 usable surveys $(19.8 \%)$ were returned. This is an acceptable response rate considering the length of the survey.

In the survey we used several earlier developed and tested scales (based upon the work of Dwyer \& Oh, 1988; John, 1984, Spekman \& Stern, 1979, Jaworski \& Kohli, 1993). As far as new scales have been developed, they have been pretested (this counts for operational control, participaction, formalization).

Furthermore, we made a distinction between two types of performance: the performance of the chain operator and the performance of the pharmacy. The chain operator's performance was measured by means of three constructs: chain operator idea generating proficiency, chain operator contribution to local responsiveness, and chain operator contribution to general performance. We measured all three constructs on 7-point Likert scales. As there were no existing scales available in the literature, we developed the items of these scales ourselves.

To measure a pharmacy's performance, we utilized subjective, self-reported measures. Subjective measures were used due to two reasons. First, objective measures (i.e. certifiable by a third party) are virtually impossible to obtain from privately held firms (Dess \& Robinson, 1984). Second, subjective measures have been shown to be correlated to objective measures of performance (Dess \& Robinson, 1984; Slater \& Narver, 1994). In an attempt to be as comprehensive as possible, we used multiple performance indicators and measurement scales. First, we selected a number of financial and operational performance indicators (e.g. gross margin, number of prescription rules, etc.) and asked respondents to report their performance in the past year. Because the financial and operational performance of pharmacies may be subject to short-term (i.e. one-year) fluctuations and therefore may not be representative of their long-term results, we also asked respondents to report the percent increase in their performance over the past three years. Second, we asked respondents to rate the financial and operational performance of their pharmacy relative to the average pharmacy in the Netherlands. The relative performance of pharmacies was measured on a 5-point Likert scale. We asked for the relative performance due to three reasons. First, it appeared from our qualitative research that pharmacists are very sensitive about releasing financial performance data. Second, during the pilot tests, some pharmacists were not able to specify their financial performance but were able to rate their performance relative to others. Third, we expected pharmacies of plural pharmacy chains to perform better than other pharmacies. In the existing literature, performance is usually measured relative to relevant competitors. However, it appeared from the pilot interviews that pharmacists generally have little insight into the performance of other pharmacies in their local environment. Because pharmacists are often aware of the performance of the average pharmacy in the Netherlands, we used the average pharmacy rather than competitive pharmacies. In addition to relative financial and operational indicators, we also 
used relative indicators that were non-economic in nature (e.g. customer satisfaction).

\section{Research Results}

\subsection{The Measurement Model: Confirmatory Factor Analysis}

We defined the different constructs that represent our conceptual frameworks. In addition, we specified the items (measures) that indicate these constructs. After examining the data, we discovered that some items that were expected to load on the same factor loaded on different factors in practice (see table 1 for an overview of the constructs that were represented by different factors). Table 1 represents the original and the new constructs. The values of the Cronbach alpha's turn out to be larger than 0.7 .

Table 1. Constructs represented by different factors

\begin{tabular}{llll}
\hline Original constructs & New constructs & $\begin{array}{l}\text { \# items per new } \\
\text { construct }\end{array}$ & Cronbach alpha \\
\hline Local responsiveness & CO contribution to local responsiveness & 3 & 0.79 \\
Adherence to uniform & Adherence to uniform front office standards & 2 & 0.91 \\
standards & Adherence to uniform back office standards & 3 & 0.89 \\
Idea generation & Contribution to idea generation & 2 & 0.82 \\
Chain operator (CO) & CO contribution to effectiveness & 6 & 0.91 \\
contribution to general & CO contribution to efficiency & 6 & 0.90 \\
performance & & & 0.95 \\
Pharmacy performance & Absolute pharmacy performance growth & 2 & 0.78 \\
& Relative performance: stakeholder satisfaction & 3 & 0.93 \\
& Relative performance: growth & 2 & 0.85 \\
\hline
\end{tabular}

\subsection{Plural Pharmacy Chains vs. Pure Pharmacy Chains}

Table 2 depicts the mean factors scores of the pharmacies of the four types of chains on this variable and the p-values of the differences in these mean factor scores: franchise pharmacies of plural chains, franchise pharmacies of pure chains, company-owned pharmacies of plural chains, and company-owned pharmacies of pure chains.

Table 2. Performance: Mean Factor Scores (MFS) of pharmacies of plural chains, franchise pharmacies of pure chains, company-owned pharmacies of pure chains, and pharmacies of pure chains and p-values of the differences

\begin{tabular}{|c|c|c|c|c|c|c|c|c|c|c|}
\hline & MFS A & MFS B & $\begin{array}{l}\text { MFS } \\
\text { C }\end{array}$ & $\begin{array}{l}\text { MFS } \\
\text { D }\end{array}$ & $\begin{array}{l}\Delta \\
\text { p-value } \\
\text { A vs B }\end{array}$ & $\begin{array}{l}\Delta \\
\text { p-value } \\
\text { A vs C } \\
\end{array}$ & $\begin{array}{l}\Delta \\
\text { p-value } \\
\text { A vs D } \\
\end{array}$ & $\begin{array}{l}\Delta \\
\text { p-value } \\
\text { B vs C } \\
\end{array}$ & $\begin{array}{l}\Delta \\
\text { p-value } \\
\text { B vs D } \\
\end{array}$ & $\begin{array}{l}\Delta \\
\text { p-value } \\
\text { C vs D } \\
\end{array}$ \\
\hline $\begin{array}{l}\mathrm{CO} \text { contribution to local } \\
\text { responsiveness }\end{array}$ & 0.27 & 0.43 & -0.46 & -0.40 & 0.340 & 0.000 & 0.003 & 0.000 & 0.001 & 0.823 \\
\hline $\begin{array}{l}\text { Adherence to uniform front } \\
\text { office standards }\end{array}$ & 0.01 & 0.25 & 0.02 & -0.40 & 0.220 & 0.958 & 0.144 & 0.212 & 0.019 & 0.138 \\
\hline $\begin{array}{l}\text { Adherence to uniform back } \\
\text { office standards }\end{array}$ & 0.19 & -1.97 & 0.60 & 0.46 & 0.000 & 0.000 & 0.041 & 0.000 & 0.000 & 0.047 \\
\hline CO idea generating proficiency & 0.14 & 0.52 & -0.47 & -0.23 & 0.036 & 0.003 & 0.082 & 0.000 & 0.001 & 0.381 \\
\hline $\begin{array}{l}\mathrm{CO} \text { contribution } \\
\text { effectiveness }\end{array}$ & 0.25 & 0.60 & -0.57 & -0.41 & 0.032 & 0.000 & 0.003 & 0.000 & 0.000 & 0.536 \\
\hline $\mathrm{CO}$ contribution to efficiency & 2.89 & 2.18 & 4.38 & 4.23 & 0.005 & 0.000 & 0.000 & 0.000 & 0.000 & 0.672 \\
\hline Absolute performance growth & -0.08 & 0.05 & -0.19 & 0.54 & 0.606 & 0.280 & 0.019 & 0.428 & 0.355 & 0.025 \\
\hline $\begin{array}{l}\text { Relative performance stakeh. } \\
\text { satisfaction }\end{array}$ & 0.24 & 0.55 & -0.67 & -0.17 & 0.081 & 0.000 & 0.019 & 0.000 & 0.001 & 0.062 \\
\hline Relative performance growth & -0.07 & 0.09 & -0.11 & 0.19 & 0.486 & 0.855 & 0.287 & 0.410 & 0.714 & 0.234 \\
\hline $\begin{array}{l}\text { Relative performance profit } \\
\text { margin }\end{array}$ & -0.17 & -0.24 & 0.07 & 0.61 & 0.784 & 0.314 & 0.007 & 0.187 & 0.003 & 0.039 \\
\hline
\end{tabular}


$A=$ Franchise pharmacies of plural chains
$B=$ Franchise pharmacies of pure chains
C $=$ Company-owned pharmacies of plural chains
$D=$ Company-owned pharmacies of pure chains

Based upon the outcomes we can accept hypothesis 1 . The chain operator contribution to the idea generating proficiency, the local responsiveness and through that the effectiveness (meeting stakeholders' requirements) is higher for franchisees than for company-owned pharmacies. Chain operators in pure forms, in franchise organizations, however still outperform the plural form on these aspects. Mixing both governance mechanisms in this stage of the development of the plural form implies giving in on local responsiveness and underlying mechanisms.

Hypothesis 2 can only be supported partly. The chain operator's contribution to the adherence of efficiency is indeed highest for company owned pharmacies. There is no significant difference between the efficiency for company owned outlets in pure and plural forms. The outcomes for the adherence to the standards are however not in line with the hypothesis. It appears significantly more franchisees will apply the standard in the front office than company owned pharmacies in pure chains. One of the underlying reasons might be, that they have contributed to the development of them and as such are more willing to use them. On the other hand, in line with the hypothesis, significantly more company owned pharmacies in pure forms stick to the back office standard compared to franchisees and corporate outlets in plural forms.

The third hypothesis can be supported. Pharmacies in plural forms are outperformed by their colleagues in pure forms. Company owned pharmacies in pure forms do show a good performance, compared to the other outlets. They score highly on absolute performance growth, relative performance growth and relative performance margin. Not surprisingly, they have difficulties in meeting the local requirements of stakeholders. It is an aspect where the franchisees in pure chains score highest, although not significantly better than their peers in plural forms.

\section{Scientific and Managerial Contributions}

\subsection{Discussion}

In this article we have combined qualitative and quantitative research methods (i.e. research triangulation). To the best of our knowledge, existing research works that have empirically investigated the benefits of the plural form have either used qualitative research methods (e.g. Bradach, 1992, 1997; Cliquet, 2000; Cliquet \& Croizean, 2002) or quantitative research methods (e.g. Heide, 2003). By using both qualitative and quantitative research methods, we have been able to provide a detailed insight and understanding of the benefits of the plural form as well as to make meaningful statistical inferences.

Most studies describe the plural form phenomenon in the context of retail chains. Restaurant chains often serve as the empirical setting of these studies (e.g. Bradach, 1992, 1997; Sorenson \& Sorenson, 2001; Srinivasan, 2006). In this article we have examined pharmacy chains rather than restaurant chains. More specifically, we have examined Dutch pharmacy chains. As far as we know, pharmacy chains have never served as the empirical context of plural form studies. In studying the benefits of the plural form, we have investigated to what extent our findings corresponded with those of Bradach $(1992,1997)$ in the restaurant sector. Broadening Bradach's work to another retail sector has demonstrated that in addition to structure, the way the positive feedback mechanism is developed by the corporate organization plays an important role in understanding conduct and thus in understanding the (potential) plural dynamics.

This article has provided insight into the different advantages of the plural form for pharmacy chains. We have demonstrated that operators of plural pharmacy chains do not fully exploit these advantages at this moment. Pharmacy chains are not yet large and established businesses. In the past these chains were mainly focused on achieving fast unit growth. Nowadays, their focus is not just on unit growth anymore but also on creating uniformity, for example. As they are still in the midst of creating uniformity, it has simply not yet become common practice for them to operationalise some of the plural dynamics.

Plural chain franchisees often have a somewhat negative bias towards the company-owned side of the chain organization as they believe company-owned pharmacies to be focused mainly on absolute performance growth rather than on pharmaceutical care (relative stakeholder satisfaction). As a result, it is not necessarily easier to persuade franchise pharmacies of plural chains to implement innovations (adherence to standards). 
We believe that ultimately it will be possible for operators of plural pharmacy chains to exploit the advantages of the plural form more fully. When plural pharmacy chains mature, it is likely to become more common practice for them to operationalize the plural dynamics. It is, however, not just a matter of time. To be able to exploit the advantages of the plural form, operators of plural pharmacy chains also have to strengthen their relationship with franchisees. They can do this by clearly demonstrating them their added value. Operators of plural pharmacy chains further also have to turn the negative bias of franchisees towards the company-owned side of the chain organization into a more positive view. To achieve this, it is important to demonstrate that pharmaceutical care is also top priority within company-owned pharmacies, and that products and services implemented in company-owned pharmacies (i.e. products and services related to sales and costs) are also beneficial to franchise pharmacies. Most likely, it will become easier to convince franchise pharmacies of the added value of such innovations when the financial situation of pharmacies deteriorates.

Simultaneously operating two different governance structures will always be a difficult managerial challenge though. It asks organizations to encompass the sharply differentiated characteristics of multiple governance structures. More specifically, it asks chain organizations to concurrently exploit the local perspective and effort of franchise outlets and the control in company-owned outlets; characteristics which are at odds with each other. Chain organizations must try to balance this duality. Variations on these dualities have been noted by other scholars. O'Reilly \& Tushman (2007), for example, focus on the difficult combination of exploitation and exploration. These authors say that successful organizations are the ones that are able to simultaneously exploit existing assets and positions in a profit producing way and to explore new technologies and markets. These organizations, what they refer to as "ambidextrous organizations," will create sustained competitive advantages. Similarly, we expect that plural pharmacy chains will also be able to generate such advantages. As described, if exploited fully, the dynamics that are produced by the simultaneous operation of franchise and company-owned outlets will cause plural chains to better meet their strategic objectives than pure chains. Considering the complexity of managing plural systems well, we believe that once achieved these advantages will be difficult to imitate. According to O'Reilly and Tushman, to succeed in being ambidextrous, it is essential for the senior management of organizations to be in agreement about the importance of both exploitation and exploration with neither being seen as more important. If not, there will be less information exchange and more unproductive conflict. Likewise, the senior management of plural pharmacy chains must value local perspective and control equally. Otherwise, it will not be able to realize the plural dynamics.

This article also demonstrated how operators of pharmacy chains can increase the performance of their pharmacies. For instance, it appeared that chain operators can positively affect pharmacies' relative performance with respect to stakeholder satisfaction by increasing pharmacies' adherence to uniform front office standards.

\subsection{Conclusion}

In this article we have rejected the assumption of existing theories (e.g. TCE and the RBV) that firms make mutually exclusive choices among governance structures. Rather, we have treated the choice of governance structure in and-and terms. Similar to existing research works on the plural form (e.g. Bradach, 1992, 1997; Cliquet, 2000; Cliquet \& Croizean, 2002; Heide, 2003; Lewin, 1997), we have presented empirical evidence on the benefits of a combination of governance structures. More specifically, we have provided insight into how the plural form enables chain organizations (i.e. pharmacy chains) to better meet their key strategic objectives. After Bradach $(1992,1997)$, we have done this by examining whether differences in the structural characteristics of franchise and company-owned outlets lead to differences in their contribution to the chain's strategic objectives (i.e. conduct), and by examining whether in combination these contributions lead to plural dynamics among the chain operator, franchise outlets, and company-owned outlets. To the best of our knowledge, there are no other studies on the plural form that have examined these relationships.

Although Bradach's study has generated novel insights into the plural form, his sampling frame only consisted of plural chains. Therefore, it precluded a specific comparison between plural and pure chains and their effectiveness in meeting strategic objectives. Because our survey sampling frame also included outlets of pure chains, we have been able to make such a comparison. Furthermore, in contrast to Bradach, we have also measured the performance implications of the plural form. This has enabled us to determine whether being part of a plural chain also leads to enhanced pharmacy performance.

In addition to Bradach's plural dynamics, our research identified two new plural dynamics. First, as described, franchise pharmacies are often much less efficiently organized than company-owned pharmacies. In order to change this, operators of plural pharmacy chains have started to offer some of the efficiency-enhancing tools used by company-owned outlets to franchise outlets. Second, the implementation of products and services in 
company-owned outlets positively influences the implementation of these products and services by franchise outlets through peer-to-peer contact. As noted earlier, the effect of this latter dynamic is not that strong (yet) as limited peer-to-peer contact exists between franchisees and company managers. Operators of pharmacy chains realize the importance of this contact though and try to stimulate it.

\section{References}

Anderson, O., \& Buvik, A. (2001). Interfirm co-ordination: international versus domestic buyer-seller relationship. Omega, 29(2), 207-219. http://dx.doi.org/10.1016/S0305-0483(00)00043-8

Andewereld-Duijvis, R. (2008). The added value of the plural form: evidence from Dutch Pharmacy chains. PhD. Dissertation, Nyenrode Business Universiteit, The Netherlands.

Botti, L., Briec, W., \& Cliquet, G. (2009). Plural forms versus franchise and company- owned systems: A DEA approach of hotel chain performance. Omega, 37(3), 566-578. http://dx.doi.org/10.1016/j.omega.2007.12.002

Bradach, J. L. (1992). The organization and management of chains: Owning, franchising, and the plural form. $\mathrm{PhD}$. Dissertation, Harvard University.

Bradach, J. L. (1997). Using the plural form in the management of restaurant chains. Administrative Science Quarterly, 42(June), 276-303. http://dx.doi.org/10.2307/2393921

Bradach, J. L., \& Eccles, R. G. (1989). Price, authority, and trust: From ideal types to plural forms. Annual Review of Sociology, 15, 97-115. http://dx.doi.org/10.1146/annurev.so.15.080189.000525

Brickley, J. A., \& Dark, F. H. (1987). An agency perspective on franchising. Financial Management, 20(1), 27-40. http://dx.doi.org/10.2307/3666094

Cliquet, G. (2000). Plural forms in store networks: A model for store network evolution. The International Review of Retail, Distribution, and Consumer Research, 10(4), 369-387. http://dx.doi.org/10.1080/09593960050138930

Cliquet, G., \& Croizean, J. (2002). Towards plural forms, franchising/company-owned systems, in the French cosmetics retail industry. International Journal of Retail and Distribution Management, 30(5), 238-250. http://dx.doi.org/10.1108/09590550210426408

Couglan, A. T., Anderson, E., Stern L. W., \& El Ansary, A. (2006). Marketing Channels (7th ed.). Upper Saddle River, New Jersey: Prenice Hall.

Dant, R. P., \& Kaufmann, P. J. (2003). Structural and strategicdynamics in franchising. Journal of Retailing, 79(2), 63-75. http://dx.doi.org/10.1016/S0022-4359(03)00011-3

Dant, R. P., Kaufmann, P. J., \& Paswan, A. K. (1992). Ownership redirection in franchised channels. Journal of Public Policy and Marketing, 11(1), 33-44.

Dant, R. P., Perrigot, R., \& Cliquet, G. (2008). A cross cultural comparison of the plural forms in franchise networks: United States, France and Brazil. Journal of Small Business Management, 46(2), 286-311. http://dx.doi.org/10.1111/j.1540-627X.2008.00244.x

Dess, G. G., \& Robinson, R. B. (1984). Measuring organizational performance in the absence of objective measures: The case of the privately-held firm and conglomerate business unit. Strategic Management Journal, 5(3), 265-273. http://dx.doi.org/10.1002/smj.4250050306

Dwyer, R. F., \& Oh, S. (1988). A transaction cost perspective on vertical contractual structure and interchannel competitive strategies. Journal of Marketing, 52(April), 21-34. http://dx.doi.org/10.2307/1251262

Ehrmann, T., \& Spranger, G. (2004). Succesful franchising using the plural form. In Windsperger, J. (Ed.), Economics and management of franchising networks. Physica Verlag, Heidelberg. http://dx.doi.org/10.1007/978-3-7908-2662-3_5

Harrigan, K. R. (1984). Formulating vertical integration strategies. Academy of Management Review, 9(4), 638-652.

Heide, J. B. (2003). Plural governance in industrial purchasing. Journal of Marketing, 67(October), 18-29. http://dx.doi.org/10.1509/jmkg.67.4.18.18689

Jaworski, B. J., \& Kohli, A. K. (1993). Market orientation: Antecedents and consequences. Journal of Marketing, 57(July), 53-70. http://dx.doi.org/10.2307/1251854 
Jaworski, B. J., \& Kohli, A. K. (1996). Market orientation: review, refinements and roadmap. Journal of Market Focused Management, 1, 119-135. http://dx.doi.org/10.1007/BF00128686

John, G. (1984). An empirical investigation of some antecedents of opportunism in a marketing channel. Journal of Marketing Research, 21(August), 278-289. http://dx.doi.org/10.2307/3151604

Kohli, A. K., \& Jaworski, B. J. (1990). Market orientation: The construct, research propositions, and managerial implications. Journal of Marketing, 54(April), 1-18. http://dx.doi.org/10.2307/1251866

Lafontaine, F., \& Kaufmann, P. J. (1994). The evolution of ownership patterns in franchise systems. Journal of Retailing, 70(2), 97-113. http://dx.doi.org/10.1016/0022-4359(94)90010-8

Lewin, S. B. (1997). Innovation and authority in franchise systems: Toward a grounded theory of the plural form. DhD. Dissertation, Harvard University.

Nunn, N. (2007). Relationship-specificity, incomplete contracts, and the pattern of trade. Quarterly Journal of Economics, May, 569-600. http://dx.doi.org/10.1162/qjec.122.2.569

O'Reilly, C. A., \& Tushman, M. L. (2007). Ambidexterity as a dynamic capability: Resolving the innovator's dilemma. Stanford Graduate School of Business, Research Paper 1963 (March).

Slater, S. F., \& Narver, J. C. (1994). Does competitive environment moderate the market orientation-performance relationship? Journal of Marketing, 58(1), 46-55. http://dx.doi.org/10.2307/1252250

Sorenson, O., \& Sorenson, J. B. (2001). Finding the right mix: Franchising, organizational learning, and chain performance. Strategic Management Journal, 22(6/7), 713-724. http://dx.doi.org/10.1002/smj.185

Spekman, R. E., \& Stern, L. W. (1979). Environmental uncertainty and buying group structure: An empirical investigation. Journal of Marketing, 43(Spring), 54-64. http://dx.doi.org/10.2307/1250741

Srinivasan, R. (2006). Dual distribution and intangible firm value: Franchising in restaurant chains. Journal of Marketing, 70(July), 120-135. http://dx.doi.org/10.1509/jmkg.70.3.120

\section{Copyrights}

Copyright for this article is retained by the author(s), with first publication rights granted to the journal.

This is an open-access article distributed under the terms and conditions of the Creative Commons Attribution license (http://creativecommons.org/licenses/by/3.0/). 